KONSTRUKTIVISME, Vol. 10, No. 2, Juli 2018

p-ISSN: 1979-9438; e-ISSN: 2442-2355

FKIP Universitas Islam Balitar, Blitar

Http://konstruktivisme.unisbablitar.ejournal.web.id; Email: konunisba@gmail.com

\title{
FAKTOR-FAKTOR PENYEBAB TINGKAT KEJENUHAN BELAJAR PENDIDIKAN AGAMA ISLAM (PAI) PADA JURUSAN PGSD DI UNIVERSITAS ISLAM BALITAR
}

\author{
Ervika Dewi Wahyuni \\ Program Studi Pendidikan Guru Sekolah Dasar, Universitas Islam Balitar Blitar \\ Email: vikadewi0@gmail.com
}

\begin{abstract}
ABSTRAK:
Penelitian ini bertujuan untuk mengetahui faktor-faktor penyebab tingkat kejenuhan belajar Pendidikan Agama Islam (PAl) pada jurusan PGSD di Universitas Islam Balitar. Kendala belajar yang dialami mahasiswa di Jurusan PGSD kelas A di Universitas Islam Balitar (UNISBA). Jenis Penelitian yang digunakan dalam penelitian ini adalah penelitian kualitatif. Metode penelitian yang digunakan adalah pendekatan kuantitatif hasil menunjukkan bahwa (1) Sikap Mahasiswa ketika Pembelajaran PAI, Temuan data observasi sesuai tabel kepada 30 mahasiswa kelas A PGSD UNISBA Blitar yang paling banyak dilakukan mahasiswa untuk mengatasi rasa jenuh di fikirannya mereka bermain game di Hanphone di jam bembelajaran, (2) Faktor Penyebab kejenuhan Belajar PAl yang terbanyak adalah bahwasanya Padatnya jam yang tidak sesuai kondisi mahasiswa mendapat respon $73 \%$. Usaha yang dilakukan Dosen untuk Mengatasi Kejenuhan Belajar PAI adalah dengan metode ceramah dan Diskusi serta penanaman akan pentingnya kerja keras.
\end{abstract}

Kata Kunci: kejenuhan, belajar, sikap, mahasiswa

\section{PENDAHULUAN}

Islam adalah agama rahmatan lil'alamin, fleksibel dan nilai-nilai ajarannya selalu diterima seperti apapun dinamika perkembangan zaman. Pada dasarnya pendidikan agama di perguruan tinggi merupakan kelanjutan dari pendidikan agama yang dilaksanakan pada jenjang pendidikan sebelumnya, yaitu mulai TK dilanjutkan ke SD, lalu ke SMP, kemudian ke SMA dilanjutkan ke perguruan tinggi

Kejenuhan adalah suatu kondisi mental di mana seseorang merasa dihinggapi kebosanan yang amat sangat untuk melakukan tugas rutin yang 
Ervika Dewi Wahyuni. 2018. Faktor-Faktor Penyebab Tingkat Kejenuhan Belajar Pendidikan Agama Islam (PAI) Pada Jurusan PGSD

di Universitas Islam Balitar. Konstruktivisme, 10 (2): 154-162

sudah sejak lama dilakukannya. Tugas rutin yang sering dihambat oleh timbulnya kejenuhan di antaranya adalah belajar dan bekerja juga diantaranya ada rasa bosan dengan PAI karena pembahasannya senderung mengulang. Untuk orang yang masih status pelajar atau mahasiswa, mereka bisa mengalami kejenuhan belajar, maka dari itu, perlu adanya inventarisasi faktor penyebab kejenuhan belajar siswa saat pembelajaran PAI serta upaya untuk mengatasi salah satu masalah pendidikan yang dialami mahasiswa yaitu kejenuhan belajar PAI. Upaya ini dimaksudkan agar tercipata pembelajaran yang aktif, inovatif, komunikatif, efektif serta menyenangkan pada mata kuliah PAI.

Berdasarkan latar belakang masalah diatas, penelitian difokuskan untuk menjawab beberapa masalah, yaitu: (1) Bagaimana sikap mahasiswa PGSD ketika mengalami kejenuhan belajar PAI? (2) Faktor apa saja yang menyebabakan kejenuhan belajar mahasiswa dalam mata kuliah PAI.

Dalam penelitiannya, Maslach dan Leiter (Yen-Jang, 2004) menunjukkan bahwa kejenuhan belajar terjadi karena beberapa faktor seperti kurangnya penghargaan, kurangnya pengawasan, beban tugas akademis yang berlebihan, konflik nilai, kurang keadilan, kurangnya persamaan dapat membuat seseorang mengalami kejenuhan.

Faktor penyebab kejenuhan dalam belajar yakni ;

1. Siswa kehilangan motivasi.

2. Kehilangan konsilidasi (kemampuan) salah satu tingkat ketrampilan tertentu sebelum siswa tertentu sampai pada tingkat berikutnya.

3. Batas kemampuan jasmaniah (karena bosan dan letih).

Penyebab kejenuhan yang paling umum adalah karena keletihan siswa meliputi indra, keletihan fisik dan keletihan mental siswa yang meliputi kecemasan, tekanan (persaingan), tuntutan yang terlalu tinggi, self-improsed (siswa mempercayai konsep kinerja akademik yang optimum, sedangkan dia sendiri menilai belajarnya sendiri hanya berdasarkan ketentuan yang ia bikin sendiri).

\section{METODE}

Penelitian ini termasuk dalam penelitian lapangan (field reserch), di Universitas Islam Balitar Jurusan PGSD di Blitar. Ditinjau dari segi sifat-sifat data maka jenis penelitian ini adalah penelitian kualitatif yang bertujuan untuk memahami fenomena social berupa kejenuhan belajar yang dialami mahasiswa dalam pembelajaran PAI di Jurusan PGSD. Pendekatan yang digunakan dalam penelitian ini adalah pendekatan psikologi belajar yaitu dengan mengkaji jiwa mahasiswa melalui gejala perilaku mereka ketika mengalami kejenuhan belajar PAI yang diamati saat proses pembelajaran di kelas. 
Ervika Dewi Wahyuni. 2018. Faktor-Faktor Penyebab Tingkat Kejenuhan Belajar Pendidikan Agama Islam (PAI) Pada Jurusan PGSD

di Universitas Islam Balitar. Konstruktivisme, 10 (2): 154-162

Waktu dan tempat penelitian. Penelitian ini dilaksanakan pada bulan November-desember 2017 pada prodi PGSD kelas A (30) anak di Universitas Islam Balitar Blitar. Data penelitian dikumpulkan melalui beberapa metode yaitu observasi, wawancara, dan dokumentasi. Uji keabsahan data yang di gunakan dalam penelitian ini adalah uji kredibilitas dengan menggunakan teknik triangulasi metode. Dalam rangka menganalisis data yang diperoleh dari hasil penelitian, diterapkan metode analisis data kualitatif, dengan tujuan memberikan predikat pada variable yang diteliti sesuai dengan kondisi yang sebenarnya.

\section{HASIL}

1. Sikap Mahasiswa ketika Pembelajaran PAI

PAI merupakan salah satu MKDU Mata Kuliah Dasar Umum yang wajib diikuti oleh mahasiwa UNISBA. Mata kuliah PAI mengacu pada RPP dan RPPS yang disusun sendiri oleh Dosen pengampu PAl, Rencana Pelaksanaan Pembelajaran yang disusun menggambarkan pengorganisasian pembelajaran untuk mencapai satu kompetensi dasar yang ditetapkan dalam standar isi dan dijabarkan dalam RPPS. Hasil observasi yang dilakukan selama 7 minggu adalah hal yang sering dilakukan Mahasiswa ketika merasakan kejenuhan saat Pembelajaran PAI di kelas antara lain:

Tabel 1 ; Sikap Mahasiswa ketika Mata Kuliah PAI

\begin{tabular}{|c|c|c|c|c|c|c|}
\hline Sikap mahasiswa & $\begin{array}{c}1 \\
\text { Minggu }\end{array}$ & $\begin{array}{c}2 \\
\text { Minggu }\end{array}$ & $\begin{array}{c}3 \\
\text { Minggu }\end{array}$ & $\begin{array}{c}4 \\
\text { Minggu }\end{array}$ & $\begin{array}{c}5 \\
\text { Minggu }\end{array}$ & $\begin{array}{c}6 \\
\text { Minggu }\end{array}$ \\
\hline a. Tidur saat di kelas & 2 anak & 1 anak & 0 anak & 3 anak & 2 anak & 2 anak \\
\hline $\begin{array}{l}\text { b. Bermain } \\
\text { handphone/Game }\end{array}$ & $\begin{array}{l}10 \\
\text { anak }\end{array}$ & 8 anak & $\begin{array}{l}10 \\
\text { anak }\end{array}$ & 6 anak & 5 anak & 4 anak \\
\hline $\begin{array}{l}\text { c. Mengganggu dan } \\
\text { ngrumpi dengan } \\
\text { teman di kelas }\end{array}$ & 2 anak & 1 anak & 3 anak & 2 anak & 1 anak & 1 anak \\
\hline $\begin{array}{ll}\text { d. Sengaja } & \text { datang } \\
\text { terlambat } & \text { lebih } \\
\text { dari sejam } & \end{array}$ & 2 anak & 3 anak & 4 anak & 2 anak & 2 anak & 1 anak \\
\hline e. Izin ke kamar & 4 anak & 2 anak & 2 anak & 2 anak & 2 anak & 1 anak \\
\hline $\begin{array}{l}\text { f. Berkomentar } \\
\text { ketika dosen } \\
\text { menerangkan }\end{array}$ & 0 anak & 1 anak & 2 anak & 1 anak & 0 anak & 0 anak \\
\hline
\end{tabular}


Ervika Dewi Wahyuni. 2018. Faktor-Faktor Penyebab Tingkat Kejenuhan Belajar

Pendidikan Agama Islam (PAI) Pada Jurusan PGSD

di Universitas Islam Balitar. Konstruktivisme, 10 (2): 154-162

Penjabaran dari tabel di atas adalah seperti dibawah ini:

a. Tidur saat Pembelajaran di kelas

Ketika Mahasiswa merasakan bosan karena dosen yang hanya ceramah, fuul jadwal dari pagi sampai sore hari juga karena banyaknya tugas kuliah di tambah pekerjaan sampingan juga organisasi kampus juga di luar kampus yang berakibat kurang tidur, akhirnya kondisi fisik tidak prima atau disebabkan asupan makanan dan tidak teraturnya jadwal makan, biasanya mahasiswa datang kemudian memilih bangku di tengah teman temannya dan tidur dengan santainya. Dari data yang di temukan tetap saja mahasiswa yang tidur di kelas. Temuan data observasi sesuai table adalah ; di minggu pertama ada2, minggu ke2 ada 1 anak, minggu ke 3 semua semangat belajar, minggu ke 4 ada 3 anak minggu ke 5 dan 6 ada 2 anak.

b. Bermain handphone

Handphone merupakan alat komunikasi yang telah umum digunakan Mahasiswa ataupun pelajar. Akan tetapi, fungsi alat komunikasi ini sering dislahgunakan dalam pemakaiannya. Ketika Dosen menerangkan di depan kelas mereka menyalakan mp3 di bangku terutama mahasiswi dimana hadsade di masukkan ke telinga dan ditutup dengan jilbab mereka. Tidak memperdulikan apa yang disampaikan oleh dosen. Temuan data observasi sesuai table adalah; di minggu pertama ada 10, minggu ke 2 ada 8 anak, minggu ke 3 ada 10, minggu ke 4 ada 6 anak minggu ke 5 ada 5 anak dan 6 ada 4 anak.

c. Mengganggu dan ngrumpi dengan teman di kelas

Di dalam kelas terdapat beberapa komunitas mahasiswa yang memiliki kepribadian yang berbeda-beda. Pasti ada saja mahasiswa yang suka mengganggu temannya bahkan di saat pembelajaran berlangsung, mereka juga tidak kehabisan bahan untuk ngrumpi di dalam kelas. Temuan data observasi sesuai table adalah ; di minggu pertama ada 2, minggu ke 2 ada 1 anak, minggu ke 3 ada 3, minggu ke 4 ada 2 anak minggu ke 5 ada 1 anak dan 6 ada 1 anak.

d. Sengaja datang terlambat lebih dari sejam

Mata kuliah PAI dilaksanakan di jam pertama, kebanyakan mahasiswa datang terlambat dengan berbagai macam alasan ada yang bangun kesiangan, tidak ada kendaraan, harus izin dari kerja, dll. Temuan data observasi sesuai tabel adalah ; di minggu pertama ada 2, minggu ke 2 ada 3 anak, minggu ke 3 ada 4, minggu ke 4 ada 2 anak minggu ke 5 ada 2 dan 6 ada 1 anak.

e. Izin ke kamar mandi

Suasana kelas yang kurang menyenangkan kadang membuat mahasiswa merasa jenuh belajar di dalam ruangan. Ada beberapa mahasiswa yang mengusir rasa bosan mereka dengan ijin keluar ruangan dan kamar mandi menjadi alasan mereka meninggalkan kelas. 
Ervika Dewi Wahyuni. 2018. Faktor-Faktor Penyebab Tingkat Kejenuhan Belajar

Pendidikan Agama Islam (PAI) Pada Jurusan PGSD

di Universitas Islam Balitar. Konstruktivisme, 10 (2): 154-162

Temuan data observasi sesuai table adalah ; di minggu pertama ada 4, minggu ke2 ada 2 anak, minggu ke 3 ada 2, minggu ke 4 ada 2 anak minggu ke 5 ada 2 dan 6 ada 1 anak.

f. Berkomentar ketika dosen menerangkan

Komentar atau berpendapat memang diwajibkan bagi mahasiswa untuk membentuk keberanian berbicara di depan khalayak ramai, tapi mereka berkomentar tentang materi di luar PAI. Temuan data observasi sesuai table adalah ; di minggu pertama tidak ada, minggu ke 2 ada 1 anak, minggu ke 3 ada 2, minggu ke 4 ada 1 anak minggu ke 5 dan 6 ada tidak ada yang berkomentar ketika proses pembelajaran.

Temuan data observasi sesuai tabel yang paling banyak dilakukan adalah bahwasanya untuk mengatasi rasa jenuh di fikirannya mereka bermain game di Hanphone yang padahal seharusnya tidak di gunakan ketika proses pembelajaran, yang dimana ini sarana yang paling mudah, karena dengan bermain game dan diam, dosen menganggap mereka mendengarkan apa yang disampaikan dosen PAl dengan skor terbanyak yaitu ; di minggu pertama ada 10, minggu ke 2 ada 8 anak, minggu ke 3 ada 10, minggu ke 4 ada 6 anak minggu ke 5 ada 5 anak dan 6 ada 4 anak.

Temuan data observasi sesuai tabel yang paling sedikit dilakukan adalah bahwasanya untuk mengatasi rasa jenuh di fikirannya adalah berkomentar ketika dosen menerangkan. Temuan data observasi sesuai table adalah ; di minggu pertama tidak ada, minggu ke 2 ada 1 anak, minggu ke 3 ada 2, minggu ke 4 ada 1 anak minggu ke 5 dan 6 ada tidak ada yang berkomentar ketika proses pembelajaran. Karena bisa di pastikan meski rasa jenuh sangat tapi mereka tidak melampiaskan pada komentar yang tidak beraturan apalagi di depan Dosen.

\section{Faktor Penyebab Kejenuhan Belajar PAI}

Kejenuhan dalam bidang apa saja pada umumnya disebabkan oleh aktifitas rutin yang dilakukan dengan cara yang monoton atau tidak berubah-ubah dalam waktu lama. Dengan demikian kejenuhan belajar lebih sering menghinggapi pelajar atau mahasiswa yang sejak SD sudah menjadi pelajar yang rajin. Penyebab kejenuhan belajar pada mahasiswa PGSD adalah: 
Ervika Dewi Wahyuni. 2018. Faktor-Faktor Penyebab Tingkat Kejenuhan Belajar Pendidikan Agama Islam (PAI) Pada Jurusan PGSD

di Universitas Islam Balitar. Konstruktivisme, 10 (2): 154-162

Tabel 2 ; Penyebab kejenuhan Belajar PAI

\begin{tabular}{|c|c|c|c|}
\hline $\begin{array}{l}\text { Penyebab Kejenuhan Belajar } \\
\text { PAl }\end{array}$ & Setuju & $\begin{array}{l}\text { Tidak } \\
\text { setuju }\end{array}$ & Tidak menjawab \\
\hline $\begin{array}{l}\text { 1. PAl tidak disukai sehingga } \\
\text { tidak focus }\end{array}$ & 5 & 25 & 0 \\
\hline $\begin{array}{l}\text { 2. Padatnya jam yang tidak } \\
\text { sesuai kondisi mahasiwa }\end{array}$ & 22 & 8 & 0 \\
\hline $\begin{array}{l}\text { 3. Ruangan atau lingkungan } \\
\text { yg kurang nyaman }\end{array}$ & 20 & 10 & 0 \\
\hline $\begin{array}{l}\text { 4. Kecemasan siswa yang } \\
\text { ditimbulkan oleh dirinya } \\
\text { sendiri }\end{array}$ & 12 & 18 & 0 \\
\hline 5. Terlalu banyak kerja intelek & 1 & 29 & 0 \\
\hline $\begin{array}{l}\text { 6. Belajar sesuai } \\
\text { keinginannya }\end{array}$ & 3 & 27 & 0 \\
\hline
\end{tabular}

Dari tabel diatas maka ditarik kesimpulan sebagai berikut ;

1. PAI merupakan mata kuliah yang tidak disukai ini ada 5 setuju dan 25 orang yang tidak setuju, PAI sebenarnya adalah matakuliah yang harus ada di seluruh Perguruan Tinggi Islam maupun Umum.

2. Padatnya jam yang tidak sesuai kondisi mahasiswa mendapat respon 22 setuju dan 8 yang tidak setuju. Kadang kondisi tubuh setiap anak berbeda-beda tergantung dari bagaimana menjaganya serta berusaha dilatih kuat menghadapi dunia kerja esok setelah lulus kuliah.

3. Ruangan atau lingkungan yang kurang nyaman mendapat 20 mahasiswa yang setuju dan 10 yang tidak setuju. Ruangan serta lingkungan memang sangat berpengaruh untuk jalannya pembelajaran, karena bisa jadi ruang pengap menjadikan dada sesak serta tidak nyamannya belajar yang ahirnya kejenuhan yang didapat.

4. Kecemasan siswa yang ditimbulkan oleh dirinya sendiri mendapat 1 mahasiswa yang setuju dan yang 29 tidak setuju. Karena menumpuknya tugas, beban keluarga atau permasalahan dengan teman bisa menjadikan timbulnya kecemasan yang berakibat pada kejenuhan serta kurangnya konsentrasi.

5. Belajar sesuai keinginan ada 3 setuju dan 27 yang tidak setuju. Kuliah harus mengikuti jadwal yang sudah di tetapkan oleh kaprodi, dan apabila akan diganti maka harus disetujui oleh dosen, mahasiswa serta kaprodi, agar suasana pembelajaran berjalan sebagaimana mestinya.

Temuan data angket yang disebarkan kepada 30 mahasiswa kelas $\mathrm{A}$ PGSD UNISBA Blitar sesuai tabel Penyebab kejenuhan Belajar PAI yang terbanyak adalah bahwasanya Padatnya jam yang tidak sesuai kondisi mahasiswa mendapat respon 22 setuju dan 8 yang tidak setuju.

Temuan data angket yang disebarkan kepada 30 mahasiswa kelas $A$ PGSD UNISBA Blitar sesuai tabel Penyebab kejenuhan Belajar PAI yang 
Ervika Dewi Wahyuni. 2018. Faktor-Faktor Penyebab Tingkat Kejenuhan Belajar

Pendidikan Agama Islam (PAI) Pada Jurusan PGSD

di Universitas Islam Balitar. Konstruktivisme, 10 (2): 154-162

sedikit adalah Belajar sesuai keinginan ada 3 setuju dan 27 yang tidak setuju.

3. Usaha yang dilakukan Dosen untuk Mengatasi Kejenuhan Belajar PAI

Metode yang diterapkan Dosen dalam mengajar PAI adalah bercerita atau ceramah, Diskusiatau Tanya jawab dan evaluasi. Dosen menyampaikan pembahasan materi pokok dengan menerangkan di depan kelas yang di dukung LCD Proyektor serta laptop sehingga mahasiswa bisa mendengarkan dan langsung mencatat sendiri bagian yang penting untuk di catat di buku mereka. Nilai yang ditanamkan dalam pembelajaran PAI bersumber dari Al-Qur'an dan as-Sunnah yang diajarkan oleh Rosululloh Muhammad SAW dalam kehidupan sehari-hari misalnya mendalami tentang rukun Iman dan rukun Islam yang harus di jalankan dan harus lebih baik di setiap harinya.

Temuan data angket yang disebarkan kepada 30 mahasiswa kelas $A$ PGSD UNISBA Blitar sesuai tabel Penyebab kejenuhan Belajar PAI yang terbanyak adalah bahwasanya Padatnya jam yang tidak sesuai kondisi mahasiswa mendapat respon 22 setuju dan 8 yang tidak setuju.

Berdasarkan temuan Angket dari pembelajaran Agama Islam (PAI), usaha yang dilakukan Dosen pengampu untuk mengatasi kejenuhan mahasiswa PGSD antara lain:

a. Penerapan metode Pembelajaran

Penerapan metode yang bervariasi sangat dibutuhkan untuk melakukan interaksi kepada mahasiswa agar dosen tidak mendominasi pembelajaran. Dengan menerapkan metode yang benar dapat menciptakan suasana pembelajaran efektif di dalam kelas.

Metode ceramah atau metode kuliah disebut juga metode pidato adalah metode memberikan uraian atau penjelasan kepada sejumlah murid pada waktu dan tempat tertentu. Dengan kata lain metode ini adalah sebuah metode mengajar dengan menyampaikan informasi dan pengetahuan secara lisan kepada sejumlah siswa yang pada umumnya mengikuti secara pasif. Dalam kamus besar Bahasa Indonesia metode ceramah adalah cara belajar atau mengajar yang menekan pemberitahuan satu arah dari pengajar kepada pelajar (pengajar aktif, pelajar pasif).

Metode diskusi adalah suatu cara mengajar dengan cara memecahkan masalah yang dihadapi, baik dua orang atau lebih yang masing-masing mengajukan argumentasinya untuk memperkuat pendapatnya. Dalam kamus besar Bahasa Indonesia metode diskusi adalah cara belajar atau mengajar yang melakukan tukar pikiran antara murid dengan guru, murid dengan murid sebagai peserta diskusi.

Sebagai usaha yang diterapkan untuk mengatasi kejeuhan di dalam kelas penulis lebih sering menggunakan dua metode sekaligus yakni metode ceramah sebagai kisi-kisi materi yang di sajikan, kemudia 
Ervika Dewi Wahyuni. 2018. Faktor-Faktor Penyebab Tingkat Kejenuhan Belajar Pendidikan Agama Islam (PAI) Pada Jurusan PGSD

di Universitas Islam Balitar. Konstruktivisme, 10 (2): 154-162

meminta membentuk kelompok serta langusung mengadakan diskusi agar mereka lebih dekat dengan teman sehingga beban yang ada di diri mereka akan perkuliahan berkurang dikarenakan forum diskusi ini melibatkan fikiran untuk bekerja tetapi juga bisa bertukar fikiran, kreasi berfikir, dengan teman di kelas juga di tampilkan video di sela-sela diskusi serta tetap dipantau oleh Dosen demi jalannya pembelajaran PAI.

b. Peningkatan Perhatian Dosen terhadap Mahasiswanya

Peran dosen sangat berpengaruh dalam pembelajaran di kelas sebagai sumber informasi maupun tempat konsultasi bagi mahasiswanya. Dosen hendaknya memperhatikan siswanya secara menyeluruh untuk mengendalikan situasi pembelajaran yang optimal.

Sebagaimana dosen adalah juga seorang guru disebut juga bapak atau ibu di kampus, bukan hal baru jika tidak jarang mendapat keluhan banyaknya jadwal pembelajaran apalagi di jam mengajar sedang berlangsung, Dosen mendengar serta membantu menyelesaikan masalah dan beruntung mata kuliah PAI jadi semua keluhan bisa mendapatkan solusi yang dikaitkan dengan Al-Qur'an serta Sunnah ulama' . dan mahasiswa harus dituntut untuk tetap semangat dimana esok mereka setelah lulus akan dihapkan pada padatnya pekerjaan serta dipastikan mereka akan siap menyelesaikan semua pekerjaan dengan baik.

\section{SIMPULAN}

1. Sikap Mahasiswa ketika Pembelajaran PAI

Temuan data observasi sesuai tabel kepada 30 mahasiswa kelas $A$ PGSD UNISBA Blitar yang paling banyak dilakukan adalah bahwasanya untuk mengatasi rasa jenuh di fikirannya mereka bermain game di Hanphone yang padahal seharusnya tidak di gunakan ketika proses pembelajaran, yang dimana ini sarana yang paling mudah, karena dengan bermain game dan diam, dosen menganggap mereka mendengarkan apa yang disampaikan dosen PAI dengan skor terbanyak yaitu ; di minggu pertama ada 10, minggu ke 2 ada 8 anak, minggu ke 3 ada 10, minggu ke 4 ada 6 anak minggu ke 5 ada 5 anak dan 6 ada 4 anak.

Temuan data observasi sesuai tabel kepada 30 mahasiswa kelas $A$ PGSD UNISBA Blitar yang paling sedikit dilakukan adalah bahwasanya untuk mengatasi rasa jenuh di fikirannya adalah. Berkomentar ketika dosen menerangkan. Temuan data observasi sesuai table adalah ; di minggu pertama tidak ada, minggu ke 2 ada 1 anak, minggu ke 3 ada 2, minggu ke 4 ada 1 anak minggu ke 5 dan 6 ada tidak ada yang berkomentar ketika proses pembelajaran. Karena bisa di pastikan meski rasa jenuh sangat tapi 
Ervika Dewi Wahyuni. 2018. Faktor-Faktor Penyebab Tingkat Kejenuhan Belajar Pendidikan Agama Islam (PAI) Pada Jurusan PGSD

di Universitas Islam Balitar. Konstruktivisme, 10 (2): 154-162

mereka tidak melampiaskan pada komentar yang tidak beraturan apalagi di depan Dosen.

2. Faktor Penyebab Kejenuhan Belajar PAI

Temuan data angket yang disebarkan kepada 30 mahasiswa kelas $A$ PGSD UNISBA Blitar sesuai tabel Penyebab kejenuhan Belajar PAI yang terbanyak adalah bahwasanya Padatnya jam yang tidak sesuai kondisi mahasiswa mendapat respon 22 setuju dan 8 yang tidak setuju.

Temuan data angket yang disebarkan kepada 30 mahasiswa kelas $A$ PGSD UNISBA Blitar sesuai tabel Penyebab kejenuhan Belajar PAI yang sedikit adalah Belajar sesuai keinginan ada 3 setuju dan 27 yang tidak setuju.

3. Usaha yang dilakukan Dosen untuk Mengatasi Kejenuhan Belajar PAI

Sebagai usaha yang diterapkan untuk mengatasi kejenuhan di dalam kelas penulis lebih sering menggunakan dua metode sekaligus yakni metode ceramah sebagai kisi-kisi materi yang di sajikan, kemudia meminta membentuk kelompok serta langusung mengadakan diskusi agar mereka lebih dekat dengan teman sehingga beban yang ada di diri mereka akan perkuliahan berkurang dikarenakan forum diskusi ini melibatkan fikiran untuk bekerja tetapi juga bisa bertukar fikiran, kreasi berfikir, dengan teman di kelas juga di tampilkan video di sela-sela diskusi serta tetap dipantau oleh Dosen demi jalannya pembelajaran PAI. Dimana mereka juga tetap diberikan pengertian akan artinya kerja keras serta kerja keras pasti akan mendapatkan hasil yang memuaskan.

\section{DAFTAR RUJUKAN}

Arikunto Suharsimi, 1990, Manajemen Penelitian, Jakarta: Rineka Cipta

Sugiyono, 2010, Metode Penelitian Pendidikan, Bandung: Alfabeta

Suwadi, dkk. 2012, Panduan Penulisan Skripsi, Yogyakarta: Jurusan Pendidikan Agama Islam, Fakultas Tarbiyah dan Keguruan UIN Sunan Kalijaga

Sukmadinata, Nana Syaodih, 2003, Landasan Psikologi Proses Pendidikan, Bandung: Rosda Karya 